\title{
Why Do We Love?
}

\section{Acylene Maria Cabral Ferreira}

Federal University of Bahia, Salvador, Brazil

Email: acylene@ufba.br

How to cite this paper: Ferreira, A. M. C. (2019). Why Do We Love? Open Journal of Philosophy, 9, 352-368.

https://doi.org/10.4236/ojpp.2019.93023

Received: June 2, 2019

Accepted: August 20, 2019

Published: August 23, 2019

Copyright (c) 2019 by author(s) and Scientific Research Publishing Inc. This work is licensed under the Creative Commons Attribution International License (CC BY 4.0).

http://creativecommons.org/licenses/by/4.0/

\section{Open Access}

\begin{abstract}
The purpose of this paper is to answer the question: why do we love? We think that we love because, as Dasein, we are constituted by ontological-existential modes, which structure us as disclosedness (Erschlossenheit) to being, to others, and to the world. Our aim is to indicate the Heideggerian concepts of existential analytic which, for us, are fundamental to grounding love as Dasein's way of being, i.e., as an ontological mode of Dasein as existence and being-in-the-world. Our hypothesis is that love is a modification of the existential of disposedness (Befindlichkeit), or an attunement (Stimmung); i.e., a way of Dasein to be attuned to somebody or to something in the world. In the first part of this paper, we will show why we can accept love as an existential mode; in the second part, we will discuss how we can say that love comes from the existential mode of being-in, of being-with and of the character of for-the-sake-of (Umwillen).
\end{abstract}

\section{Keywords}

Love, Attunement, Existential Mode, For-the-Sake-of, Being-In, Being-With

\section{Introduction}

The question in this paper is one which we have already asked ourselves at some moment in our lives: why do we love? Obviously, many novelists, poets and thinkers, such as psychoanalysts, philosophers, sociologists, anthropologists etc., have already written on the theme of love. They have spoken about this theme from different conceptual perspectives, and they have tried to say what our behavior is when we love, and they have also described what love is and how it is concretized. There is no doubt that in the history of mankind love has already been exhaustively sung about, romanticized, discussed and debated in different areas of knowledge from distinct points of view. If we take this as a fact, then we can state that love or its deficient mode- hate as the lack of love-is the basis on which part of our individual history, and simultaneously part of the history of 
the world, is rooted. In this way, for example, we can say that love or hate is implicit in many political decisions, disagreements on religious beliefs, moral behaviors, racial or gender intolerance, the struggles of social classes, and so on. We can go further and say that love, as well as hate, moves and grounds a lot of our actions. From that perspective, we can conclude that love and hate are affections which occupy a privileged place in human life. However, the strength of this conclusion and the centrality of these affections neither supplant the need to explain what leads us to write one more paper about love, nor detain us from explaining what contribution we intend to add to this theme. In order to follow our explanation about love, first we need to set out the philosophical context in which we will speak about love.

Because our purpose is to investigate how, philosophically, we can define "love" as a mode of being, i.e, as an existential modification of Dasein, we have chosen Heideggerian hermeneutic-phenomenology as our research method. Thus, methodologically, we will base our research procedure on the existential analytic. As well as in hermeneutic-phenomenology the existential analytic is considered the analysis method that structures the modes of being of Dasein, for defining "love" as an existential modification of Dasein, conceptually, we will take as our analysis method the existential analytic described in Prolegomena: History of the Concept of Time (1925), Being and Time (1927), The Metaphysical Foundations of Logic (1928), and in texts like What Is Metaphysics? (1929), On the Essence of Ground (1929) and Letter to Humanism (1946). We will also refer to Zollikon Seminars (1959-69), because in Seminars Heidegger indicates that we can reflect about love from the existential analytic, if we correlate love to care (Sorge), i.e. if we connect love to the ontological wholeness of the structural whole of Dasein. As our purpose in this paper is to think about which concepts of existential analytic are fundamental to grounding love as a mode of being that constitutes Dasein as existence and being-in-the-world, we will not deal with the different ways of romantic love here. So we will not analyse the letters which Hannah Arendt and Heidegger wrote to each other. We do not intend to determine a concept of love in Heidegger's thought, but only to indicate the concepts with which we presuppose that it is possible to speak about love in hermeneutic-phenomenology. Our hypothesis is that love is a modification of the existential of disposedness (Befindlichkeit) ${ }^{1}$, or an attunement (Stimmung); i.e. a way of Dasein to be attuned to somebody or something in the world.

In The Fundamental Concepts of Metaphysics. World, Finitude, Solitude, in an effort to explain the meaning of Stimmung better, Heidegger correlates Stimmung to a melody which sets the tone for Dasein's being. For him, Stimmung tunes, attunes and determines the manner and the way in which Dasein is what it is. Stimmung is "precisely a fundamental manner $[A r t]$ and a fundamental way [Weise] of being, indeed of being-there [Da-sein], and this always di-

${ }^{1}$ John Macquarrie and Edward Robinson (Heidegger, 2008) translate Befindlichkeit as "state-of-mind". Joan Stambaugh (Heidegger, 2010) translates it as "attunement". We translate it as "disposedness" following Daniel O. Dahlstrom (2013: p. 62). 
rectly includes being with one another" (Heidegger, 1995: p. 67). Exactly because Heidegger named one of the existential structures that determines Dasein "Stimmung," and explained that this existential attunes Dasein to others and to the world, we will translate "Stimmung" as "attunement" following William McNeill and Nicholas Walker's translation (Heidegger, 1995). Because we understand that the word "attunement" reflects more clearly the existentiell meaning of "Stimmung" as an ontic phenomenon derived from the existential of disposedness. It means that Stimmung or attunement is a modification of disposedness. For us, the word "attunement" shows the mode of Dasein in which it is being-together-with the world as well as being-with the other Dasein more sharply. In this case, we think that using the word "attunement", on one hand will let us see the connecting and tuning of disclosedness (Erschlossenheit) of Dasein with itself, with another Dasein and with something in the world more easily. On the other hand, we think that when we choose to use the word "attunement" instead of the word "mood," in a certain way, this will help us to analyze how love is an existential modification of Dasein. Why?

For example: when a person has a relationship with their brother or sister, and this person attunes to them in the mode of love, in this kind of relationship, we say that their attunement to the other consists in a fraternal mode of loving. But if the same person is in a relationship with their parents, and this person attunes to them in the mode of love, in this kind of relationship, we say that this person is in a filial mode of loving, and so on. Following Heidegger's statement that "attunements are the fundamental ways in which we find ourselves disposed in such and such a way" (Heidegger, 1995: p. 67); we can deduce that, as an attunement, love is a fundamental mode of being of the entity which we ourselves are: Dasein. That means that an attunement (love, hate, sadness, happiness etc.) is a mode through which we, as Dasein, situate ourselves for ourselves and for others in the world.

In order to defend the hypothesis that love is an existential modification, an attunement, we will take this well known statement from Zollikon Seminars. "care is never distinguishable from 'love' but is the name for the ecstatic-temporal constitution of the fundamental characteristic of $\mathrm{Da}$-sein, that is, the understanding of being" (Heidegger, 2001: p. 190). Based on this, on the phenomenological-hermeneutic method and on the concepts of existential analytic, we intend to show that the existential structures which constitute Dasein are modified in accordance with the mode in which Dasein opens itself to being, to others and to something in the world. In accordance with these modes of disclosedness or openness Dasein attunes or unattunes itself to others and to something in the world.

It is necessary to underline that every way of Dasein tuning to somebody or to something in the world is a mode of attunement, that's why "attunements are the 'how' [Wie] according to which one is such and such a way" (Heidegger, 1995: p. 67). This means that there are different ways of attunement, depending ${ }^{2}$ Joan Stambaugh as well as John Macquarrie and Edward Robinson translate Stimmung as "mood". 
on 'how' Dasein attunes. This is the reason why attunements constitute the fundamental mode which gives Dasein subsistence, and from which Dasein situates its being-with-one-another in the world.

From Heidegger's phenomenological-hermeneutic theoretical framework, we can enumerate some reasons which move us to write a paper about love: [i] the challenge to extract a concept of love from existential analytic; [ii] the possibility of conceiving love as an existential modification; [iii] to define love as an existentiell mode of attunement; [iv] to be able to offer one more possible answer to the question: why do we love? Thus, we can say that the contribution of our paper to the issue of love is to propose a version of love derived from the ontological-existential constitution of Dasein. Our purpose is to clarify that we love because as Dasein we are determined as disclosedness to being, to others, and to the world. It is on account of this ontological-existential determination that Dasein can set the tone for and attune to somebody or to something in the world. We intend to show that depending on the mode of attunement in which, as Dasein, we are situated in the world, we can say that we love someone, an animal, some knowledge, etc. In this paper we will not discuss the wish to be loved by someone. Neither is it important to us to discuss if someone is loved by the person with whom they are in love, nor to talk about whether someone is loved or not. From this perspective, we understand that feeling loved is, certainty, different from loving.

We will divide our paper in two parts. In the first, we will show why we can accept love as an existential mode; in the second, we will discuss how we can say that love comes from the existential mode of being-in, of being-with and of the character of for-the-sake-of (Umwillen). What is the connection between these two parts? If we intend to define love as an existential modification of Dasein, first of all we need to show that love is a mode of being, in which Dasein attunes to somebody or to something in the world. From this procedure, we can analyse that love is a mode of being derived from the existentials of being-in and of being-with, from which Dasein is characterized as for-the-sake-of. While disposedness is an openness of being of Dasein that is rooted on the existential of being-in, we can consider that the existential of disposedness is the condition of possibility for any mode of Dasein encountering someone or something in the world. It allows us to conclude that love is rooted on disposedness, i.e, that love is an existential modification of disposedness: a mode of attunement.

\section{Love as an Existential Modification}

Why do we presuppose that it is possible to conceive of love from the existential analytic? First, because in Zollikon Seminars Heidegger suggested that we can know what love is by connecting it to care, understanding of being and ecstatic-temporality, concepts which set the theoretical structure of the existential analytic. Second, because some scholars have written about love from the existential analytic, as we propose here. For example, Giorgio Agamben wrote that 
for Heidegger love is facticity, a character of the existential of falling, in which Dasein is in the mode of being of inauthenticity, where Dasein attunes in the mode of being of others. This is why he considered love as the passion of facticity, as an impotentiality of freedom that keeps Dasein in irreducible inauthenticity (See Agamben, 2008: p. 105, 107). Similar to Agamben, but in a different manner, Françoise Dastur sets her reflection about love in the ontological character of authenticity and inauthenticity that constitute Dasein's modes of being in the world. She claims that seduction, understood as the most common way of Dasein being with one another, is rooted on the disclosedness of "they" [Man]. This kind of disclosedness is determined by the character of idle talk, curiosity and ambiguity. These characters constitute the inauthentic mode of being of Dasein. From this perspective, for Dastur, seduction is grounded in the existential of falling, and for this reason, she considers that seduction is an inauthentic mode of being of Dasein (See Dastur, 2012: p. 165), in which Dasein is in general determined "even in its fullest concretion, when it is busy, excited, interested, and capable of pleasure" (Heidegger, 2010: p. 42). We can say that in the same manner in which for Heidegger authenticity is a modification of inauthenticity (See Heidegger, 2010: p. 126), for Dastur love is "like a conversion from inauthenticity into authenticity, which most probably does not happen very often" (Dastur, 2012: p. 169). In other words, love is a conversion from seduction into an authentic mode of being of Dasein. Differently from Agamben and Dastur, who centralize their reflections about love on the existential of falling, Marcia Schuback also bases her reflection about love on the concepts of the existential analytic, following the same statement from Zollikon Seminars as Agamben and Dastur. Thus she states that "love is for Heidegger Sorge [care], that is, transcendence" (Schuback, 2012: p. 139), since care is understood as an authentic movement of ecstatic-temporality. This means that while love is understood as care and transcendence, it is temporality. In this case, love is the condition of possibility for articulating the existentiality of Dasein.

Like Agamben, Dastur and Schuback, who have demonstrated in distinct ways that is possible to elaborate a "phenomenology of love" based on some concepts of the existential analytic (See Dastur, 2008: p. 119), we also intend to go to the existential analytic, with the purpose of explaining why we love. Instead of dealing with the concepts of falling, care, transcendence and ecstatic-temporality like Agamben, Dastur and Schuback, we will deal with the concepts of disposedness, attunement, being-in, being-with and the character of for-the-sake-of. Taking into account that in Zollikon Seminars (See Heidegger, 2001: p. 190) Heidegger links love to the understanding of being, and in Being and Time he states that the existentials of understanding and of disposedness are co-belonging (See Heidegger, 2010: p. 183), we presuppose that the co-belonging of the existentials of being-in and of disposedness will help us to conceive of love as a mode of being in which Dasein attunes to the world, i.e., as an existential modification of Dasein. Why?

On one side, of the three characters of disclosedness that belong to the exis- 
tential of disposedness, the actual disclosure of the whole of being-in-the-world is the one which enables Dasein to attune to other Dasein in the everyday world. This other to whom Dasein tunes itself in the world, Heidegger named Dasein-with. On the other side, because the mode of being of thrownness, which is a character of the existential of being-in, is the condition of possibility of Dasein affecting others, and consequently being affected by others. Based on the existential of disposedness, we intend to show how love, as an attunement (an ontic-existentiell mode of being), i.e., as a fundamental way of Dasein being with one another, is derived from the existential of being-in and from the the character of for-the-sake-of. We will only be able to explain how love is an existential mode of attunenment of Dasein to someone or something in the world, if first we come back to the concepts of existence and being-in-the-world, because these concepts are the grounding of disposedness, attunement, being-in and for-the-sake-of.

The first constitution of being of Dasein in Being and Time is existentiality. Heidegger calls "the very being [Sein] to which Dasein can relate in one way or another, and somehow always does relate, existence [Existenz]" (Heidegger, 2010: p. 11). This means that Dasein can be one way or another while it exists. Whereas Dasein is determined essentially as existence, the ontological characters that structure the modes of being of Dasein are called existentials (See Heidegger, 2010: p. 44). The kind of understanding that Dasein has of itself and from which it understands itself as singularity situated in the world at a certain time, is named existentiell understanding (See Heidegger, 2010: p. 11). The fundamental constitution of being, which gathers all existentials and existentiell determinations of Dasein is designated being-in-the-world. This is a primordial, a primary and "an a priori necessary constitution of Dasein" (See Heidegger, 2010: p. 54). The existentials that compound the unified and inseparable phenomenon of being-in-the-world are: being-in, being-together-with [Sein bei] and being-with. In spite of all these existentials being co-originary, we can say that the existential of being-in is the most originary structure of being of Dasein, because it is the basis on which the existentials of being together with the world and of being-with others are rooted (See Heidegger, 2010: pp. 54-55).

Thus, the expression "being-in-the-world," which compounds the ontological-existential unity that structures Dasein, means the same as existence, i.e., being-thrown-together-with other entities in the surrounding world. While Dasein is structured as being-in-the-world, it is rooted on its existence and determined essentially as disclosedness to being. Heidegger states in the Introduction to "What Is Metaphysic?" that in Being and Time existence "names a way of Being; specifically, the Being of that being which stands open for the openness of Being in which it stands in withstanding it" (Heidegger, 1998d: p. 283-284). To say that Dasein is existence is to say that it is being-in rooted in the disclosedness to being; in other words the mode in which Dasein exists is the mode of being opened to the understanding of being of other entities which are together with it in the surrounding world. How is Dasein determined from the co-belonging existen- 
tials (being-in, being-together-with, being-with) that compound the unified structure of being-in-the-world?

While Dasein is structured by the existential of being-together-with, Dasein affects and is affected by the world. In this constitution of being Dasein understands the significance of the world and determines the worldliness of the entities which it deals with. In this way, Dasein is being-together-with-the-world, and it is charaterized as the entity which exists in for-the-sake-of-which (See Heidegger, 1992a: p. 202). While Dasein is structured by the existential of being-in, it is determined by its facticity, i.e., by the mode in which it is and in which it is thrown in the world: disclosedness to being and to the world. In this constitution of being Dasein can show its being in an authentic or inauthentic mode and, simultaneously, it can understand the being of Dasein-with in the same mode of being in which it is: disclosedness. At the same time, Dasein can understand and discover the being of innerworldly entities. Speaking ontologically, the being of these entities is determined by categories, but only if these categories are understood as "to let it [something] be seen for everyone in its being" (Heidegger, 2010: p. 44). Then Dasein is for-the-sake-of-being and for-the-sake-of-potentiality-of-being. While Dasein is structured by the existential of being-with, it is disclosed to Dasein-with. In this kind of disclosedness, in which Dasein encounters Dasein-with, it can encounter itself, just as Dasein understands its being while it understands the being of other Dasein. In this sense, Dasein depends on the other to constitute itself as the entity which it can and has to be. Thus, Dasein is for-the-sake-of-others (See Heidegger, 2010: p. 120). In fact, "others are, rather, those from whom one mostly does not distinguish oneself, those among whom one also is" (Heidegger, 2010: p. 115). While Dasein is constituted as being-with, we can say that it exists in the mode of being-withone-another. The reason why Dasein-with and Dasein live in different kinds of society or community consists in their rootedness on the existential of being-with, in which they are attuned in the mode of being-with-one-another.

From these considerations we can claim that the existential of being-with is a fundamental constitution of being-in-the-world (See Heidegger, 1992a: p. 241). Why? Because "Dasein as being-with is lived by the co-Dasein [Dasein-with] of others" (Heidegger, 1992a: p. 245). In other words: in this constitution of being-with-one-another, Dasein-with and Dasein understand themselves as being-with. It is in this understanding of being that the attunement and the encountering of being-with of Dasein with the being-with of Dasein-with happens. It is in this encounter that the mode of attunement in which Dasein and Dasein-with are tuned to each other is grasped. Since love demands encountering and attuning to the other, and because Dasein and Dasein-with are structured existentially as being-with-one-another, we presuppose that the existential of being-with is fundamental for conceiving love as a mode of being of Dasein. Obviously there are many ways for Dasein and Dasein-with to live being-with-one-another, for example, wishing, wanting, hating, respecting, envying, disdaining, etc. But it is 
important to highlight that all these ways of living being-with-one-another depend on "how" Dasein and Dasein-with are attuned to each other. This is why attunement determines the modes in which Dasein and Dasein-with are in the world.

In Letter on "Humanism" we find this following statement: "to embrace a 'thing' or a 'person' in their essence means to love them, to favor them" (Heidegger, 1998c: p. 241). From this quotation we understand that "to embrace" means "to wish someone or something well." In this sense "to embrace" means to care, to nurture, that is, to love. Based on the correlation that we have made between the terms "to love" and "to wish well," we can infer that in an existentielle mode of being-with-one-another Dasein and Dasein-with understand themselves as being in different ways of "wishing well," that is, in different ways of love. While Dasein is structured existentially as being-with-one-another, it can understand the mode of being-with of Dasein-with as to wish well, thus it can encounter and situate itself in a determined way of love. In this existential constitution Dasein and Dasein-with are tuned and attuned in the mode of being of love. From such an understanding we can state that the existential structure of being-with-one-another is the condition of possibility for us to conceive of love as an existential modification of being of Dasein. Hence, while Dasein is being-with Dasein-with, it is characterized as for-the-sake-of-others. This implies that Dasein directs itself to another Dasein-with in different ways, including that of love. In accordance with the different ways of attunement of wishing well in which Dasein and Dasein-with can encounter themselves, we assume that they can exist and live in different ways of love, for example: romantic, seductive, sexual, marital, friendly, parental, filial, maternal love etc.

\section{Love and the Character of For-the-Sake-of}

Considering that being-with-one-another is an ontological determination of the existential of being-with, in which Dasein is for-the-sake-of-others, and also considering that the existential of being-with is rooted on the existential of being-in and of being-together-with, in which Dasein is for-the-sake-of-which, for-the-sake-of-being and for-the-sake-of-potentiality-of-being, we can claim that the character of "for-the-sake-of" co-belongs to the existentials of being-in, being-together-with and being-with. This means that this character consists in an ontological connection (Zusammenhang) that constitutes the unified structure of being-in-the-world. From these considerations we can say that the character of "for-the-sake-of" is fundamental to the constitution of the ontological-existential totality of Dasein as existence (potentiality of being) and being-inthe-world. While Dasein is for-the-sake-of-being, for-the-sake-of-potentialityof-being, for-the-sake-of-others and for-the-sake-of-which, Dasein is also forthe-sake-of-itself (Umwillen seiner), i.e., for-its-own-sake (See Heidegger, 1992b: p. 191. See also Heidegger, 1998a: p. 122). Why? Because the being of Dasein is grasped as disclosedness. From this ontological determination of being Dasein 
can understand itself as being-its-self (Selbstsein). Dasein can understand itself in this mode of being because it is determined by the movement of directionality, in which it directs toward itself, toward someone or toward something in the world reciprocally. We based these considerations about the character of "for-the-sake-of" on The Metaphysical Foundations of Logic. There, Heidegger says that the term "for-the-sake-of," methodologically, is an extreme existential-ontological model (See Heidegger, 1992b: p. 190). Why is it possible to consider the character of "for-the-sake-of" as an ontological connection that constitutes the existential wholeness of being-in-the-world?

While the existentials of being-in, being-together-with and being-with are an ontological modification of the unified structure of being-in-the-world, the existential determinations of for-the-sake-of-being, for-the-sake-of-potentiality-of-being, forthe-sake-of-others, for-the-sake-of-which and for-the-sake-of-itself are ontological modifications of the existential character of "for-the-sake-of." From this ontological-existential connection between the unified structure of being-in-theworld and the character of for-the-sake-of, the existential of being-together-with the world is characterized as the determination of for-the-sake-of-which something is understood and constituted in one mode of being or another. From this ontological-existential connection Dasein understands and grasps the worldliness of the world that constitutes the worldly mode of being of Dasein and the worldliness of the entities which are within-the-world (innerweltlich). In this ontological-existential connection Dasein is for-the-sake-of-which in the world. Meanwhile the existential of being-in, which determines the facticity and the singularity of Dasein, is structured for the existential characters of for-the-sakeof-being and for-the-sake-of-potentiality-of-being; but the existential of being-with is determined for the existential characters of for-the-sake-of-itself and for-the-sake-of-others which set the being-with-one-another of Dasein and Dasein-with ontologically. What correlation can we make between love and the existential modification of the character of for-the-sake-of?

In order to answer this question, we will take the existential modification of the character "for-the-sake-of-itself," because while Dasein is constituted by this existential-ontological character, it directs itself toward being-its-self. Simultaneously to this movement of directionality, Dasein directs itself toward its potentiality of being, toward something or toward somebody in the world. This implies that in this movement of directionality Dasein exists in the mode of being directed toward. We can say that while Dasein is rooted on this character of directionality, Dasein is determined for the ontological reciprocity between the existentials of being-in, being-together-with and being-with; existentials which constitute the wholeness and the structural unity of being-in-the-world. Rooted on this ontological-existential character of for-the-sake-of-itself, Dasein exists in the mode of selfhood (Selbstheit), as such Dasein is determined for the character of selfsameness (Selbigkeit). Respecting the existential and structural reciprocity of being-in-the-world, and the determination of the mode of being of Dasein as 
selfhood, we can afirm that there is an ontological connection between the characters of for-the-sake-of-itself and of selfsameness. We can further add that in this ontological connection the character of selfsameness is derived from the character of for-the-sake-of-itself (See Heidegger, 1992b, p. 191).

Strategically, we will take the character of for-the-sake-of-itself to reflect about love, because according to Heidegger, "existing is precisely this being toward oneself. [...] Moreover, being toward oneself as being as self is the presupposition for the various possibilities of ontic relations to oneself" (Heidegger, 1992b: p. 189). If we assume that existing means being toward oneself and that existence coincides with the concretization of the ontic relations of any Dasein in the surrounding world, we presuppose that the character of for-the-sake-of-itself can be taken as one of the pillars for our reflection about love as an existential modification of Dasein. Why? Simply and irrefutably because love consists in an ontic-existentielle relation of Dasein with something in the world or with a Dasein-with.

Similar to the existential mode of being-with-one-another, in which Dasein can compromise itself to the being-with of Dasein-with, we assume that the character of for-the-sake-of-itself is fundamental to the concept of love as an existential modification of Dasein, i.e., as a mode of attunement. How? While selfsameness is a modification of the character of for-the-sake-of-itself, we can infer that selfsameness is a fundamental character for the constitution of Dasein as being-in-the-world. Hence, we can afirm that selfsameness is a fundamental character of the relation of Dasein with itself and, reciprocally, with the other or with something in the world. If love is understood as a relationship of Dasein with someone or something in the world, why have we chosen the character of for-the-sake-of-itself as the ground for answering the question "why do we love?" instead of the character of for-the-sake-of-others? More incisively: why we are taking the being toward selfhood as the basis to speak about love, as a mode of attunement of Dasein, instead of taking the being toward others or toward something in the world?

While selfsameness is presupposed for the ontic relations of Dasein in the surrounding world in The Metaphysical Foundations of Logic, selfsameness is presupposed for the Ihood [Ichheit] of Dasein and for the mode in which Dasein "is able to comport itself either egoistically or altruistically" (Heidegger, 1998a: p. 122) in On the Essence of Ground. From this perspective selfsameness is the condition of possibility for an I-self and for a You-self. However, selfsameness does not coincide with an I or with a You. In fact, selfsameness is "neutral with respect to being an 'I' and being a 'you'" (Heidegger, 1998a: p. 122), as well as with respect to selfhood. It means that selfsameness grounds Ihood, from which Dasein understands itself as a You-self with respect to Dasein-with, and through which others understand themselves as an I-self with respect to Dasein. Selfsameness is the basis for grounding the being-its-self of Dasein and of Dasein-with. It is exactly because selfsameness is defined by the character of neutrali- 
ty that it can ground one or another mode of being of Dasein. While Dasein exists in the mode either of selfhood, or of I, or of You, it is possible to claim that the being of Dasein is determined for the character of selfsameness, which is derived from the character of for-the-sake-of-itself.

From the existentiell way of being Dasein understands being-its-self as an I. This "I" is a formal indication that Dasein uses in its everyday life to refer to itself, when it speaks about itself to others. While Dasein refers to itself as an I, it refers to the Dasein-with as a You. But from the existential way of being, Dasein understands being-its-self as the potentiality-of-being which itself is. Thus, it understands itself as possibility, in this case, it understands its selfhood authentically. When Dasein understands being-its-self as an "I" instead of possibility or potentiality-of-being, Dasein understands its selfhood as if it were an entity which is present-at-hand in the world. It means that Dasein understands its being as factuality. From this perspective Dasein understands itself in an inauthentic mode of being, which Dasein is usually in. Ontologically and existentially, selfsameness can be considered the grounding of the being-its-self of Dasein. In an ontical-existentiell way this being-its-self discloses Dasein as Ihood, i.e., as an I or a You. It is "only because Dasein as such is determined by selfhood can an I-self comport itself toward a you-self" (Heidegger, 1998a: p. 122). This means that Dasein can exist as an I, as a You, because as being-in-the-world it is determined by the mode of being-with, in which it directs toward itself and toward Dasein-with.

As selfsameness is a modification of the character of for-the-sake-of-itself, we presuppose that the constitution of being of selfsameness can be considered as the grounding for love as an existential modification. Why? Because while Dasein exists in the mode of an I, it can direct toward a You as the mode of being of Dasein-with, and both are in the mode of being-with-one-another. Because Dasein and Dasein-with are characterized as for-the-sake-of-others, an I-self can attune to a You-self in distinct modes of being, among which we can find the different possible modes of love. Exactly because Dasein and Dasein-with can attune to each other in the mode of love, and because in this attunement they are able to live a loving relationship, we defend that love is an existential modification which determines the ontical-existentiell modes in which Dasein relates itself with someone or something in the world.

In parallel to being-with-one-another we understand that selfsameness is the ontological grounding of love, because while Dasein is determined by selfsameness it can understand itself either as an authentic selfhood, in which it is potentiality-of-being, or as an inauthentic selfhood, in which it can be either an I, a You or a We. From this perspective we can add that the distinction between these constitutions of being of selfhood, which are derived from the character of for-the-sake-of-itself, can be correlated to the distinction between the authentic and inauthentic modes of Dasein. This allows us to say that both of these modes of being-its-self are constituted by selfsameness and are derived from the cha- 
racter of for-the-sake-of-itself. In other words we can claim that the authentic and inauthentic modes of selfhood are an existential modification of the character of for-the-sake-of, and co-belong to the structural unity of being-in-theworld. From these considerations, we can infer that in the same way that Dasein is determined by the ontological connection between the character of for-thesake-of and the unified structure of being-in-the-world, it is determined by the ontological connection between the characters of for-the-sake-of-itself and of selfsameness. These connections are therefore fundamental to explaining why Dasein exists as being-with-one-another. In this mode of being Dasein is determined by the character of for-the-sake-of-others. Why do we presuppose that the character of selfsameness grounds love as an existential modification or an attunement of Dasein?

While Dasein is characterized as for-the-sake-of-itself, it is determined as selfsameness and directed toward selfhood. In this mode of selfsameness Dasein can understand its being as I-self or potentiality-of-being instead of an I and, simultaneously, it can also understand the being of Dasein-with as a You-self or potentiality-of-being instead of a You. From this constitution of being Dasein understands itself as possibility of being instead of Ihood. Thus, Dasein understands itself and Dasein-with outside the I-You relationship, in which both are determined by the mode of being of Ihood and Youhood. While Dasein is determined by the character of Ihood, it is characterized as for-the-sake-of an I, of a You, of a She, of a He, i.e., for-the-sake-of someone or something in the world. So, we can say that when selfsameness is the grounding of authentic selfhood, it is the grounding of the mode of love between I-self and You-self. But when selfsameness is the grounding of Ihood, it is the grounding of the mode of love between an I and a You, between us and them, between she and he etc. It is necessary to highlight that in both modes of constitution of the being of selfsameness and in the various possible determinations of love, Dasein unsderstands its selfhood as a mode of being-with-one-another, even when it is loving itself, and it is characterized as Ihood. As we asserted previously Dasein understands its own being when it understands the being of Dasein-with. Because selfsameness caracterizes the authentic and the inauthentic selfhood (I, You, She, He etc.) as modes of being of Dasein in the world, i.e., because selfsameness is the character that determines an existential modification in which Dasein can encounter itself or can encounter others or something in the world, we presuppose that while selfsameness is an existential modification of the character of for-the-sake-ofitself, selfsameness can be considered as one of the bases that grounds love as an existential modification. Rooted on this modification Dasein can attune to Dasein-with or to something in the world. Because selfsameness characterizes inauthentic and authentic selfhood, Dasein will "ever be either egoistic or altruistic" (Heidegger, 1992b: p. 117).

Because in hermeneutic-phenomenology the character of selfsameness is derived from the character of for-the-sake-of-itself, and because we assume that 
these characters ground love as an ontic-existentiell relation of Dasein, it is plausible that we consider love as derived from the character of for-the-sake-of. From this perspective, we can defend that this character grounds "love" as an existential modification of Dasein. While Dasein is determined by the character of for-the-sake-of, it can be for-the-sake-of-being, for-the-sake-of-potentialityof-being, for-the-sake-of-itself, for-the-sake-of-others and for-the-sake-of-which. In this existential-ontological determination the being of Dasein is structured as directing toward itself, toward others and toward something in the world. In others words, Dasein is structured as disclosedness to being, disclosedness to someone or to something in the world.

Because of these determinations of being, we defend that Dasein can love itself, others or something in the world. In this way we are confirming Heidegger's statement that "as constituting the selfhood of Dasein, the for-the-sake-of has this universal scope" (Heidegger, 1992b: p. 191). While the character of for-thesake-of is a fundamental existential modification of Dasein, this character determines the ontic-ontological constitution of the world and of Dasein. In other words while Dasein is determined by the character of for-the-sake-of, it is constituted by the ontological-existential characters of worldliness and selfsameness, through which Dasein understands the being of innerworldly entities, the being-its-self and the being of Dasein-with. This means that while Dasein is constituted by the existential of worldliness and for the character of selfsameness, it is structured as being-in-the-world.

For us, the character of for-the-sake-of is fundamental to grasping love as an existential modification of Dasein. Why?

The for-the-sake-of is what it is in and for a willing. But the latter does not mean the existentiell-ontic act of will, but means rather the intrinsinc possibility of willing: freedom. (...) Rather, freedom is itself the origin of the for-the-sake-of. (...) Freedom is, rather, one with the for-the-sake-of (Heidegger, 1992b: 191).

Considering that the character of for-the-sake-of connects the structural unity of being-in-the-world, and further considering that this character is one with freedom, it is possible to claim that "being-in-the-world is freedom" (See Heidegger, 1992b: p. 192). If we take this connection of freedom with the character of for-the-sake-of and the structural unity of being-in-the-world, and take our statement that the character of for-the-sake-of is fundamental for grasping love as an attunement, i.e., as an existential modification, then we can infer that freedom is fundamental for grasping love as an existential modification of Dasein.

Despite the importance of freedom to the constitution of the existentiality of Dasein and for the reflection of love as an existential modification, we will not go into the issue of the connection of love and freedom deeply here, because we have already dealt with this theme in our article entitled Love as Attunement (See Ferreira, 2018). From the considerations that we made in that article we will 
return to the conception that in hermeneutic-phenomenology freedom is taken as letting-Dasein-be what it is and what it is possible for it to be. In this conception, freedom coincides with the ontological connection between the disclosedness to being, the disclosedness to the world and the disclosedness to others, which constitute Dasein as existence. From the ontological connections of these ways of disclosedness, we can affirm that freedom connects the characters of for-the-sake-of-being, for-the-sake-of-potentiality-of-being, for-the-sake-of-which, for-the-sake-of-itself and for-the-sake-of-others, which determine Dasein as being-in-the-world. From this perspective, we can say that while freedom conncects these existential ways of disclosedness of Dasein with the modifications of the character of for-the-sake-of, "freedom is the highest necessity" (Heidegger, 1951: p. 42) for constituting the modes of being of Dasein, in which we can include love as a mode of attunement.

Freedom as '[B]eing attuned (...) can be 'experienced' and 'felt' only because the 'human being who experiences,' without being aware of the essence of the attunement, is always engaged in being attuned in a way that discloses being as a whole" (Heidegger, 1998b: p. 147). We can infer from this quotation that as a mode of attunement freedom engages and unfolds every mode of love in its provenance, on which the disclosed comportment of Dasein and of Dasein-with are rooted. Hence, freedom engages and unfolds every mode of love which comes from the relation between the I-self of Dasein and the You-self of Dasein-with. Because freedom is grasped as an attunement, i.e., as an existential modification of disposedness, and because the character of for-the-sake-of springs from freedom, we claim that freedom grounds the authentic modes of love. How? Because freedom is conceived as an ontological connection which links the characters of disclosedness of Dasein, and because in hermeneutic-phenomenology the existentials which structure the being of Dasein are determined by the characters of disclosedness and of closedness; in our article entitled Love as Attunement, we assume that the inauthentic mode of love is based on the character of closedness, which belongs to the attunement of freedom (See Ferreira, 2018: pp. 149-152). From the presuppostion that love is based on the attunement of freedom and also that love is a mode of Dasein in which it is attuned to others or to something in the world, we can confirm that love is an existential modification of disposedness, i.e., a mode of attunement. Why? Because disposedness is rooted on the existential of being-in. In this way disposedness is grasped as a fundamental mode of being-in, which is one of the structures that compounds the unity of being-in-the-world.

\section{Conclusion}

Considering 1) that in the existential of being-in Dasein is determined by the characters of for-the-sake-of-being and for-the-sake-of-potentiality-of-being, 2) that the existential of being-in co-belongs to the existentials of being-with and being-together-with, in which Dasein is determined by the characters of for-the- 
sake-of-itself and for-the-sake-of-others and 3) that when Dasein directs itself toward the world and toward others, Dasein directs itself toward selfhood, we can affirm that because Dasein is determined by disposedness, it is able to encounter itself as being-its-self while it encounters Dasein-with as being a Youself, and at the same time it is still able to discover the meaningfulness of the world (Heidegger, 1992a: p. 255). These considerations allow us to infer that the existential of disposedness is the condition of possibility for any mode of Dasein encountering someone or something in the world. Then disposedness is the grounding to self-encountering-itself of Dasein. Why do we affirm that disposedness is a fundamental existential for Dasein encountering someone or something in the world?

In the ontological analytic the existential of disposedness is characterized by three essential determinations of disclosedness: 1) the disclosure of throwness, 2) the actual disclosure of the whole of being-in-the world and 3) the prior disclosedness of the world (See Heidegger, 2010: p. 133). Because Dasein is determined by these ways of disclosedness of disposedness, it is able to affect and to be affected by someone or something in the world, and simultaneously it is able to situate itself in the world in one way of attunement or another. While disposedness is the existential that structures the being of Dasein as disclosedness to the world, it is the existential that grounds the character of disclosedness of the facticity of Dasein. In other words, the disclosedness of disposedness determines the factual character in which Dasein always exists in one mode of being or another. It is important to highlight that the character of factuality of Dasein does not coincide with facts or data as if it were something of nature, because Dasein is not an innerworldly entity, rather it is an entity which is disclosed and thrown to the world.

Existentielly, we can say that the facticity of Dasein coincides with the way in which Dasein is attuned to the world. This means that facticity correlates to attunement. That is why, ontically, we can affirm that attunement is a mode of being which determines the worldly character of Dasein. We can also claim that attunment grounds the relations in which Dasein is thrown in a certain way in the world. From this perspective, disposedness "means always already being in the world; [... as] a being disposed toward the disclosed world" (Heidegger, 1992a: p. 257). So, disposedness is a mode of being-in that refers us to the existentials of being-with and being-together-with, in which Dasein is for-the-sakeof-itself, for-the-sake-of-others, and for-the-sake-of-which. Thus, we can conclude that disposedness is a genuine existential through which we can conceive of love as a mode of Dasein being disposed in the world, encountering others or being-together-with something in the world. Why? Because disposedness is a fundamental mode of being-in, which determines the facticity and the possible modes of encountering of Dasein. As Dasein is existentielly determined by disposedness, it is able to encounter Dasein-with and to exist in many modes of being-with-one-another, for example in a loving or hating mode. The different 
modes of being depend on "how" Dasein and Dasein-with attune themselves with each other.

Because of that we defend that love is an existential modification of disposedness, and therefore a mode of attunement in which Dasein is being-with-others, i.e, in which it is for-the-sake-of-itself, for-the-sake-of-others and, reciprocally, for-the-sake-of-being, for-the-sake-of-potentiality-of-being and for-the-sake-ofwhich. Considering that the character of for-the-sake-of emerges from freedom, existentielly, Dasein understands love as a way of wishing someone or something in the world well. As such love can be considered as an ontic-existentiell mode of Dasein, in which Dasein is able to encounter itself, others or something in the world. It is why we defend the idea that love originates from the ontological connection between the existentials of disposedness, of being-in, of being-together-with and of being-with-one-another and the characters of for-the-sake-of and selfsameness. Finally, we can answer the central question of this article: Why do we love? We love because as Dasein we are constituted as existence, structured as being-in-the-world and characterized as disclosedness to being, to others or to something in the world. Ontologically and existentially, as Dasein, we are determined as disposedness, being-with-one-another, for-the-sake-of-others, for-thesake-of and as wishing well. Existentielly and ontically, we are able to live in different modes of love, depending on the way that we set the tone and attune to others or to something in the world.

\section{Conflicts of Interest}

The author declares no conflicts of interest regarding the publication of this paper.

\section{References}

Agamben, G. (2008). The Passion of Facticity. In F. Raffoul, \& E. Nelson (Eds.), Rethinking Facticity (pp. 89-112). Albany, NY: State University of New York Press.

Dastur, F. (2008). Binswanger lecteur de Être et temps: Amour, nostrité et souci. In P. Cabestan, \& F. Dastur (Eds.), Lectures d'Être et temps de Martin Heidegger: Quatre-vingts ans après (pp. 101-120). Argenteuil: Le Cercle Herméneutique.

Dastur, F. (2012). The Phenomenological Question of the Relation with the Other: Love, Seduction and Care. In J. Bornemar, \& M. Schuback (Eds.), Phenomenology of Eros (pp. 153-168). Södertörn: Södertörn University.

Ferreira, A. M. C. (2018). Love as Attunement. Open Journal of Philosophy, 8, 85-101. https://doi.org/10.4236/ojpp.2018.82008

Heidegger, M. (1951). Hölderlin und das Wesen der Dichtung. In Erläuterungen zu Hölderlins Dichtung (pp. 33-48). Frankfurt: Vittorio Klostermann.

Heidegger, M. (1992a). History of the Concept of Time: Prolegomena (Translated by Kisiel, T.). Bloomington and Indianapolis, IN: Indiana University Press.

Heidegger, M. (1992b). The Metaphysical Foundations of Logic (Translated by Heim, M.). Bloomington and Indianapolis, IN: Indiana University Press.

Heidegger, M. (1995). The Fundamental Concepts of Metaphysics. World, Finitude, Solitude (Translated by McNeill, W. and Walker, N.) Bloomington and Indianapolis, IN: 
Indiana University Press.

Heidegger, M. (1998a). On the Essence of Ground. In W. McNeill (Ed.), Pathmarks (pp. 97-135, Translated by McNeill, W.). Cambridge: Cambridge University Press.

Heidegger, M. (1998b). On the Essence of Truth. In W. McNeill (Ed.), Pathmarks (pp. 136-154, Translated by Sallis, J.). Cambridge: Cambridge University Press.

Heidegger, M. (1998c). Letter on "Humanism". In W. McNeill (Ed.), Pathmarks (pp. 239-276, Translated by Capuzzi, F.A.). Cambridge: Cambridge University Press.

Heidegger, M. (1998d). Introduction to "What Is Metaphysic?" In W. McNeill (Ed.), Pathmarks (pp. 287-290, Translated by Capuzzi, F.A.). Cambridge: Cambridge University Press.

Heidegger, M. (2001). Zollikon Seminars (Translated by Mayr, F. and Askay, R.). Evanston, IL: Northwestern University Press.

Heidegger, M. (2008). Being and Time (Translated by Macquarrie, J. and Robinson, E.). New York: Harper Perennial.

Heidegger, M. (2010). Being and Time (Translated by Stambaugh, J., Revised by Albany, D.J.S.). New York: State University of New York Press.

Schuback, M. (2012). Heideggerian Love. In J. Bornemar, \& M. Schuback (Eds.), Phenomenology of Eros (pp. 129-152). Södertörn: Södertörn University. 